\title{
発生時刻と継続時間を考慮した 都市停電の影響度評価
}

\author{
秦康範 ${ }^{1} \cdot$ 川北潤 ${ }^{2} \cdot$ 目黒公郎 ${ }^{3} \cdot$ 山崎文雄 ${ }^{3} \cdot$ 片山恒雄 $^{4}$ \\ ${ }^{1}$ 正会員 博（工） 人と防災未来センター（广 651-0073 兵庫県中央区脇浜海岸通 1-5-2） \\ ${ }^{2}$ 工修 大成建設株式会社 土木本部 (₹ 163-0606 新宿区西新宿 1-25-1 新宿センタービル) \\ 3 正会員 工博 東京大学生産技術研究所（₹ 153-8505 東京都目黒区駒場 4-6-1） \\ ${ }^{4}$ 正会員 Ph. D 独立行政法人 防災科学技術研究所（广305-0006 茨城県つくば市天王台 $3-1$ )
}

近年, 都市化の進展とともにエネルギ一需要における電力への依存性が高まっており, 停電が都市生活に 与える影響は極めて大きくなっている. 本研究では, 都市停電の定量的影響度評価手法を提案し, 東京 23 区 の配電用変電所に適用を試みた. すなわち,「停電の影響」を「平常時に行っている生活活動ができなくなっ てしまう状態」と定義し、「停電の影響度」を「停電により妨げられた平常時ならば行っているはずの生活 活動の重要度の合計」として評価する手法を構築した. また提案手法を東京 23 区の配電用変電所に適用し, 電力需要分析ならびに各配電エリアの停電影響度マップの作成を行った.

Key Words: power outage, lifeline, power load curve, Tokyo Metropolis, substation

\section{1.はじめに}

近年の都市社会は電力に強く依存しており, 電 力消費量も，それがエネルギー全体の消費に占め る割合も増加する傾向にある. 一世帯当たりの電 力の消費量および全エネルギーに占める構成割合 は, 1970 年度にそれぞれ $1,571 \times 10^{3} \mathrm{kcal}, 25.0 \%$ であったのが, 1980 年度は $2,878 \times 10^{3} \mathrm{kcal}, 33.8 \%$, 1990 年度は $3,973 \times 10^{3} \mathrm{kcal}, 38.1 \%, 1999$ 年度に は $4,758 \times 10^{3} \mathrm{kcal}, 43.5 \%$ と全体の消費量および 構成割合ともに増加の一途を歩んでいる ${ }^{1)}$.2001 年 7 月には, 東京電力管内での最大電力が 5 回も更 新された．このようにエネルギー消費における電 力依存が高まる中で, 停電による影響も大きなも のとなっている. ライフラインの途絶による被害 波及・連鎖においては, 電力供給の途絶は他シス テムへの影響が大きく ${ }^{2), 3)}$, 停電による被害を最小 に抑えるための事前対策, 及び迅速な復旧・復興 対策を立案するためにも, 電力の供給停止が社会 生活に与える影響を定量的に把握する手法の確立 が重要となっている.

一方, 平常時における電力供給の信頼性は極め て高く, 1999 年度の東京電力管内で需要家一軒当
たりの停電回数は 0.18 回/年, 停電継続時間は 4 分 / 年となっている ${ }^{4)}$. ライフラインの供給支障の 影響を定量化する研究としては, 塩野・朱牟田 ${ }^{5)}$, 能島・亀田・林 ${ }^{6), 7)}$ によるライフライン途絶による 生活支障の定量化の研究, 川崎・長橋 ${ }^{8)}$ の上水道の 機能停止による生活支障の定量化の研究があるが, これらは地震災害時の長期間に及ぶライフライン の途絶を取り扱ったものである.

本研究では, 発生頻度の高い日常的に発生する 規模の停電（最長でも 1 日程度）を対象とし, 停電 の発生時刻および継続時間によって変化する停電 の影響を，定量的に評価できる手法を提案する．次 に, 提案手法を東京 23 区の配電用変電所に適用し, 配電エリアごとの停電影響度マップを作成する.

\section{2. 停電影響度評価モデル}

\section{(1) 配電エリアの電力需要}

本研究で評価する地域エリアは，一般需要家を 対象として電力供給を行っている配電用変電所と した. 都市部の電力需要は, 住宅, オフィス, 工場, 店舗 / 飲食店の 4 つの電力需要パターンの組み合 わせとして式 (1) のように表現できることが報告さ 
れている ${ }^{9}$.

$$
y_{j}(t)=\sum_{i=1}^{4} \alpha_{j i} x_{i}(t)
$$

ここで, $y_{j}(t)$ は配電エリア $j$ の電力需要, $\alpha_{j i}$ は配 電エリア $j$ の電力需要パターン $i$ の軒数, $x_{i}(t)$ は時 刻 $t$ における電力需要パターン $i$ の 1 軒あたりの平 均電力需要である. ただし, $i$ は各構成要素 $(i=1$ : 住宅, 2 : オフィス, $3:$ 工場, $4:$ 店舗/飲食店)で ある. また配電エリア $j$ の時刻 $t$ における正規化し た電力需要 $\bar{y}_{j}(t)$ は, 4 パターンの正規化した電力 需要 $\bar{x}_{j i}(t)$ と寄与率 $C_{j i}$ 用いて, 式 (2) のように表 すことができる(図ー1） ${ }^{9}$.

$$
\bar{y}_{j}(t)=\sum_{i=1}^{4} C_{j i} \bar{x}_{j i}(t)
$$

本研究においても, 配電エリアの電力需要がこ の 4 パターンに分類できることを利用し, 停電影響 度評価モデルの構築を行う。

\section{(2) 対象とする停電}

本研究で対象とする停電は 1 日（24 時間）程度 としているが，これは日常的に発生する停電を対 象としているためであり, その根拠は以下の通り である。

図ー 2 は新聞検索 ${ }^{10)}$ による停電事例調査の集計 結果である.これによると首都圈（東京, 神奈川, 埼玉，千葉）で新聞記事になる程度の規模の停電が 毎年 20 から数十件発生している. その継続時間は 最長でも 6 時間以内であり, その多くは 90 分程度 である. 日本海中部地震 $(1983)^{11)}$, 釧路沖地震 $(1993)^{12)}$, 北海道東方沖地震 $(1994)^{13)}$, 鳥取県西部 地震 $(2000)^{14)}$, 芸予地震 $(2001)^{15)}$ など, わが国で 発生した近年の地震による停電についても, 停電 戸数は一般の停電事故に比べて大規模になるが, 継続時間は多くの風水害による停電（図－2）同様 1 日以内である. 宮城県沖地震 $(1978)^{16)}, 19$ 号台風 (1991) ${ }^{17)}$, 兵庫県南部地震 $(1995)^{18)}$, 東海豪雨 $(2000)^{19)}$ においては, 応急復旧にそれぞれ1日半 から 1 週間程度を要したが, このような長期間の停 電は例外的である.またこうした大規模災害にお いては, (1)地域が大きく被災するため, 平時に発生 する停電の影響とは性質が異なる（例えば, 家屋被 害や浸水被害が多数発生し, 多くの住民が避難活 動をしている地域などを想定した場合, 住民が受 ける停電の影響は平時とは異なるだろう), (2)停電 に伴って波及する社会的影響が大きく長期に及ぶ, といった特徵があり, 停電の性質も影響も日常的 に発生する停電とは異なると考えられることから，

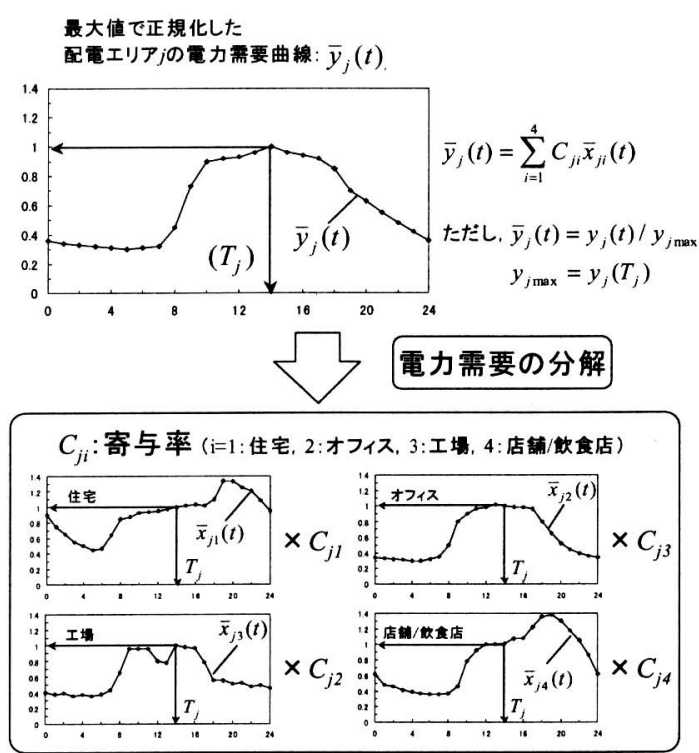

図-1 タイプ別の電力需要算定法の概要

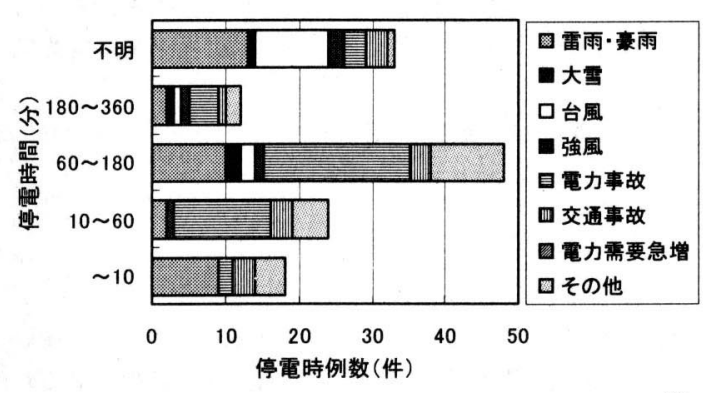

図一 2 新聞検索による停電事例 (1991 年〜 2000 年) ${ }^{10)}$ （停電継続時間別に見た停電事例数）

1 日を超えるような長期間の停電は本研究の対象外 とした.

\section{（3）停電の影響度の定義}

本研究では「停電の影響」を,「平常時に行って いる生活活動ができなくなってしまう状態」と定 義し, 各生活活動の重要度（価值）を評価して,「停 電により妨げられた平常時ならば行っているはず の生活活動の重要度の合計」を停電影響度として 評価する.

各配電エリアの停電影響度は, その配電エリア 内の各パターンの潜在的影響度の和で表されるの で, 停電が時刻 $t_{s}$ に発生し, 時間 $t_{d}$ だけ継続した場 合に，この停電が配電エリア $j$ に及ぼす影響 $E_{j}\left(t_{s}, t_{d}\right)$ は,

$$
E_{j}\left(t_{s}, t_{d}\right)=\sum_{i}^{4}\left\{r_{i} \cdot e_{j i}\left(t_{s}, t_{d}\right)\right\}
$$


と表せる. ただし， $i=1$ : 住宅，2：オフィス， 3 : 工場, 4 : 店舗 / 飲食店である. また, $r_{i}$ は電力需 要特性パターン間の重みを表す係数, $e_{j i}\left(t_{s}, t_{d}\right)$ はパ ターン別潜在的影響度である.

\section{（4）停電影響度評価基準}

各配電エリアの潜在的停電影響度を比較すると き, その評価基準としては, (1)消費電力の量, (2) 停電の影響を受ける人口, (3)電力の使われ方, の 3 つを用いる.つまり消費電力および停電の影響 を受ける人口が多いほど, 停電の影響が大きいと した．また，停電の影響は同じ地域でも電力の使 われ方（業種ごと，時間帯ごとの重要性の差）に よって異なると考えられることから，本研究では 各パターンの平均的な 1 軒当たりの消費電力を影 響度の評価基準とし, 対象とする配電エリアの消 費電力と人口の積で相対的に比較する. 電力需要 パターン $i$ の潜在的停電影響度 $e_{j i}\left(t_{s}, t_{d}\right)$ は, 次のよ うに表せる.

$$
e_{j i}\left(t_{s}, t_{d}\right)=\int_{t_{s}}^{t_{s}+t_{d}}\left\{P_{j i} \cdot \alpha_{j i} \cdot R_{j i}(t) \cdot U_{i}(t)\right\} d t
$$

ここで, $P_{j i}$ は配電エリア $j に お け る$ 電力需要パター ン $i$ ごとの消費電力の補正係数, $\alpha_{j i}$ は配電エリア $j$ 内の電力需要パターン $i$ の需要家数, $R_{j i}(t)$ は時刻 $t$ における配電エリア $j$ 内の電力需要パターン 1 軒 あたりの人口, $U_{i}(t)$ は電力需要パターン 1 軒あた りの潜在的停電影響度である. 式 (4) から, $e_{j i}$ は [人 口] - [影響度] - [時間] という次元を持つことと なる. なお, $P_{j i}$ は配電エリア $j$ の電力消費量とその 全配電エリア平均との比であり,

$$
P_{j i}=\left(C_{j i} y_{j \max }\right) /\left(\alpha_{j i} x_{i \max }\right)
$$

と表される。

\section{（5）潜在的影響度と必要度関数}

図一 3 に示すように, 電力需要特性パターン $i$ で 対象となる電力消費対象機器を $k$ とすると, $k$ を利 用する比率は時刻によって変化する。これはその 機器の時刻別の必要度の変化と考えられることか ら, これを電力需要パターン $i$ で用いられる機器 $k$ の必要度関数 $\left(h_{k i}(t)\right)$ と呼ぶこととする. パターン $i$ の 1 軒あたりの潜在的影響度 $U_{0 i}(t)$ は $h_{k i}(t)$ を用い $\tau$,

$$
U_{o i}(t)=\sum_{k} h_{k i}(t)
$$

と表される. なお必要度関数は日照時間, 就業・営 業時間の平均, NHK の国民生活調查 ${ }^{20)}$ 等から以下

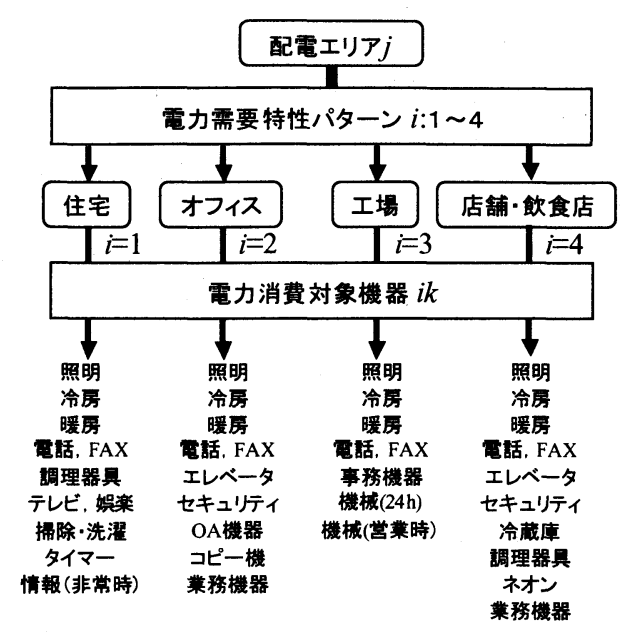

図ー3 各電力需要パターン内の消費対象機器

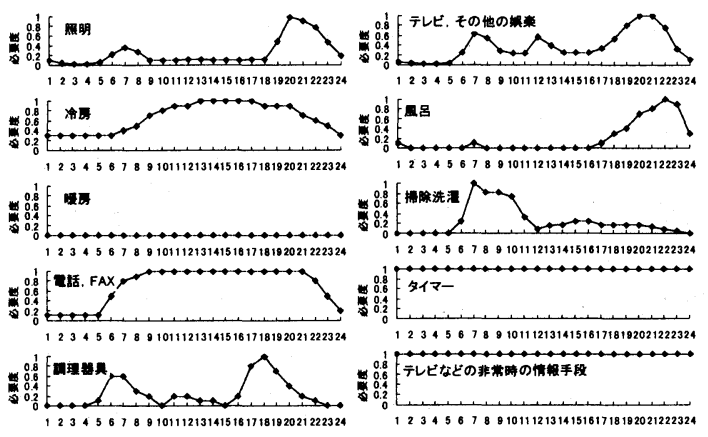

図-4 各電力消費対象機器の正規化必要度関数 $\left(\beta_{k i}(t)\right.$, 住宅, 夏)
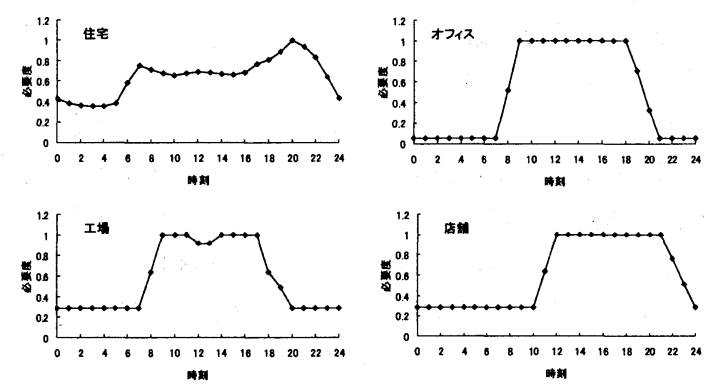

図-5 タイプ別の正規化必要度関数の和 $\left(U_{i}(t)\right.$, 夏)

のように推定した. 図ー4 は住宅タイプの夏の電力 消費対象機器の必要度関数を例として示したもの である. 各季節, 各パターンごとに電力消費対象機 器の必要度関数を作成している. ただし, 図一 4 は その消費対象機器が最も必要とされる時刻での值 が 1 になるように正規化しており，この曲線を正規 化必要度関数 $\left(\beta_{k i}(t)\right)$ とする. 必要度関数の最大 
值 $H_{k i}(t)$ と $\beta_{k i}(t)$ を用いると式 (6) は,

$$
U_{0 i}(t)=\sum_{k} h_{k i}(t)=\sum_{k} H_{k i}(t) \beta_{k i}(t)
$$

と表される. $U_{k i}(t)$ はパターン間の電力消費対象機 器数の違い等があり, パターン内の相対的な比較 は可能であるが，パターン間の比較が困難である. そこでカーブの形状だけを議論するため, 式 (4) で は式 (8) で定義された $U_{i}(t)$ を使用することとした (図-5).

$$
U_{i}(t)=U_{o i}(t) / \sum_{k} H_{k i}
$$

なお図ー4 は夏の晴れた暑い日を想定したケース を表しているが，季節，天候，平日や休日の違いと いった要因も,この関数を修正することで容易に 取り込むことが可能である.

\section{（6）慣れ・遅れ関数と機能支障関数}

停電の継続時間が数分程度の短い時間ならば, 利用者は何も困惑を感じないと考えられる（これ を「困惑の発現の遅れ」と呼ぶ). また停電が長時 間継続した場合，慣れによって困惑の度合いが軽 減されることもある. 能島ら ${ }^{6)}$ はこうした傾向を, 時間遅れ項を評価関数に組み込んで表現している. 本研究においても慣れ・遅れ関数 $m_{i k}(t)$ を用いて, これらを表現する. 図ー6 (a) はこの $m_{i k}(t)$ の定義で ある. 慣れ・遅れ関数は困惑の程度を表しており, その最大值は 1 となる. また関数の原点は「停電後

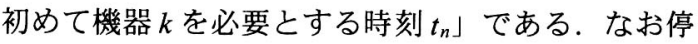
電が発生してもしばらくはその機能を維持できる 場合（例えば冷蔵庫を考えた場合，停電後のある時 間内であれば，冷蔵庫の保温性によって，中の物が 腐るといつた問題が発生しない，など）は，図ー6 (b) に示す機能支障関数 $f_{i k}(t)$ を用いてこの効果を表 す. 機能支障関数の最大值は, 慣れ・遅れ関数同様 1 であるが, 関数の原点は停電発生時刻 $t_{s}$ である. これらの慣れ・遅れ関数, および機能支障関数を使 用すると，式 (4)，(7)，(8) は

$$
\begin{gathered}
e_{j i}\left(t_{s}, t_{d}\right)=\int_{t_{s}}^{t_{s}+t_{d}}\left\{P_{j i} \cdot a_{j i} \cdot R_{j i}(t) \cdot V_{i}(t)\right\} d t \\
V_{0 i}(t)=\sum_{k} H_{k i}(t) \beta_{k i}(t) \cdot m_{k i}(t) \cdot f_{k i}(t) \\
V_{i}(t)=V_{o i}(t) / \sum_{k} H_{k i}
\end{gathered}
$$

と書き直せる．なお本論文では遅れを表す曲線部 分はコサインカーブと仮定し, 遷移部分の長さを 表す機器 $k$ の使用を我慢できる時間を $t_{p}$ とした（図

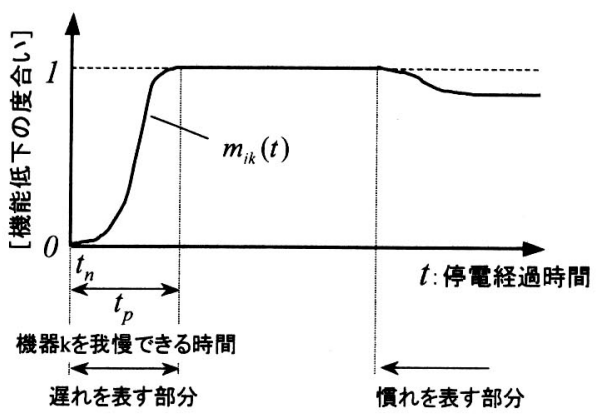

(a) 慣れ・遅れ関数

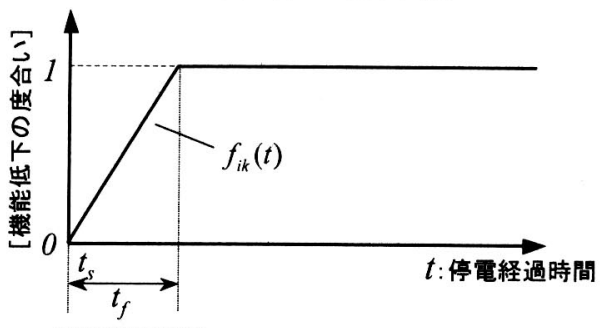

機能維持時間

(b) 機能支障関数

図-6 電力消費機器 $k$ の慣れ・遅れ関数之機能支障関数

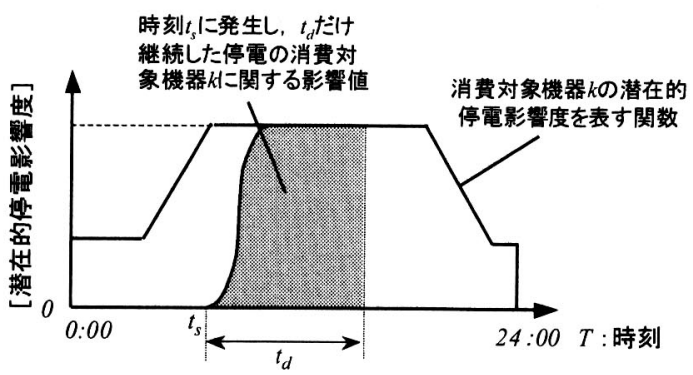

図-7 停電影響度の時間積分の概念図

ー 7). また計算において慣れを表す部分は，これ を定量化する十分なデータがないために今回は考 慮しなかった。

\section{(7) 配電エリアごとの停電危険度指標}

防災においては, 各配電エリアの潜在的な停電 影響度を考慮した上で, 適切な事前対策を講じる ことが重要であるが, 停電がいつ発生し, どれだけ 継続するかは事前にはわからない。そこでここで は, 適切な事前対策を講じるために, 停電発生時刻 や停電継続時間を総合的に考慮した配電エリアご との停電危険度を表す指標 (PI: Power outage Index) を, 式(12)，式(13)のように $P I_{1}, P I_{2}$ としてそれぞ れ提案する.

$$
P I_{1}=\operatorname{Max}\left[E_{t_{d}}\left(t_{s}\right), t_{s}=0,23\right]
$$


（a）各電力消費対象機器の照明の重要度に対する重み

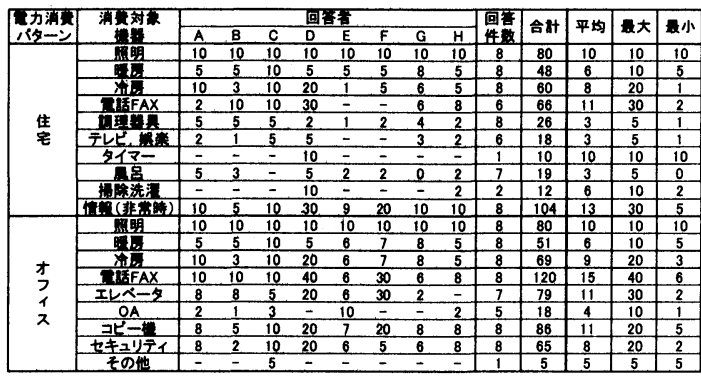

表一２ アンケートから各電力需要特性パターンの照明に 対する重み

\begin{tabular}{|c|c|c|c|c|c|c|c|}
\hline \multicolumn{8}{|c|}{ 各パターンの照明に対する五み } \\
\hline \multicolumn{2}{|l|}{ 住宅 } & \multicolumn{2}{|c|}{ オフィス } & \multicolumn{2}{|l|}{ 工场 } & \multicolumn{2}{|c|}{ 店䚂/领食店 } \\
\hline 照明 & 10 & 照明 & 10 & 照明 & 10 & 照明 & 10 \\
\hline 暖屏 & 5 & 暧原 & 5 & 暖屏 & 5 & 暖原 & 5 \\
\hline 冷层 & 5 & 冷原 & 7 & 冷首 & 7 & 冷屏 & 8 \\
\hline Z話FAX & 8 & Rififfax & 10 & D話FAX & 8 & 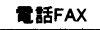 & 8 \\
\hline 旬理繁具 & 5 & エレベータ & 10 & $O A$ & 10 & エレベータ & 10 \\
\hline テレビ, 㖽脊 & 3 & セキュリティ & 2 & 旔诚(24h) & 20 & セキュリティ & 5 \\
\hline 周呂 & 2 & パソコン & 10 & 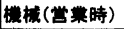 & 20 & 冷藏庫 & 20 \\
\hline 搹賖洗潍 & 2 & コピー機 & 5 & & & 期理譏器 & 10 \\
\hline タイマー & 2 & 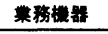 & 5 & & & ネオン & 15 \\
\hline 情般 (非常時) & 10 & & & & & 畨弱樴器 & 6 \\
\hline
\end{tabular}

$$
P I_{2}=\sum_{t_{s}=0}^{23} E_{t_{d}}(t s)
$$

$P I_{1}$ は，継続時間 $t_{d}$ の停電を設定し，ある配電エリ アで 1 日の各時刻 $t_{s}$ に停電が発生した場合の停電影 響度 $E t_{d}\left(t_{s}\right)$ を比較して，そのうち最も大きな影響 度の値を, その配電エリアの停電危険度とするも のである，PI 2 は，同様にして継続時間 $t_{d}$ の停電が 1 日の各時刻に発生した場合の総和をその配電エリ アの停電危険度とするものである． $P I_{1}$ が大きい配 電エリアは，停電が発生した場合にその影響度が 大きくなる可能性があることを示し， $\mathrm{PI}_{2}$ の值が大 きい配電エリアは1日を通じて平均的に影響度が 大きいことを示す.

\section{3.アンケート調查}

\section{(1) アンケートの目的}

本研究では「停電の影響度」を「停電により妨げ られた平常時ならば行っているはずの生活活動の 重要度の合計」と定義しているが, 各生活行動の相 対的な重要性は個人によって違いがある。そこで, (b) 停電後, 各電力消費対象機器の 使用を我慢できる時間（分）

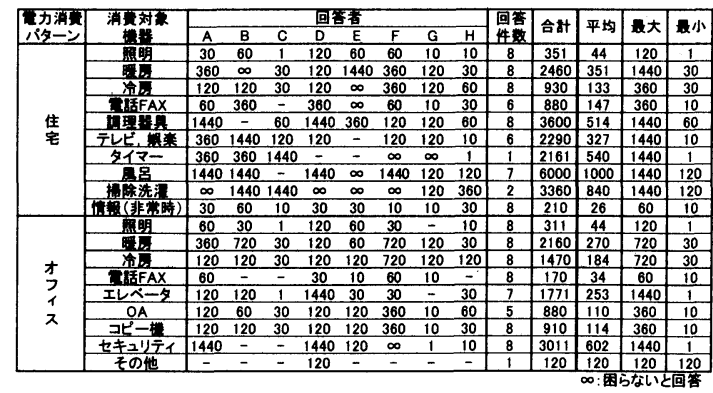

表ー 3 アンケートから得た各電力消費機器の使用を我慢 できる時間（分）

\begin{tabular}{|c|c|c|c|c|c|c|c|}
\hline \multicolumn{2}{|l|}{ 住宅 } & \multicolumn{2}{|c|}{ オフィス } & \multicolumn{2}{|l|}{ 工场 } & \multicolumn{2}{|c|}{ 店镇/飲食店 } \\
\hline 照明 & 30 & 照明 & 10 & 照明 & 30 & 照明 & 10 \\
\hline 暖层 & 60 & 暖屏 & 60 & 暖屏 & 60 & 暧房 & 30 \\
\hline 冷房 & 60 & 冷俤 & 120 & 冷局 & 120 & 冷屏 & 30 \\
\hline T話FAX & 60 & T話FAX & 30 & 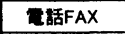 & 60 & T話FAX & 60 \\
\hline 5理器具 & 120 & エレベータ & 30 & OA & 30 & エレベータ & 120 \\
\hline テレビ，埧萑 & 360 & セキュリティ & 60 & 譏械(24h) & 10 & セキュリティ & 60 \\
\hline 周呂 & 720 & パソコン & 60 & 樴械(棠業時) & 10 & 冷蔵革 & 60 \\
\hline 摛除洗熦 & 1440 & コピー桠 & 60 & & & 暗理機器 & 30 \\
\hline タイマー & 120 & 䚄務機器 & 60 & & & ネオン & 120 \\
\hline 情報 (非常時) & 30 & & & & & 桬務機器 & 30 \\
\hline
\end{tabular}

表 -4 各季節の電力需要記録日と諸元

\begin{tabular}{|c|c|c|c|c|c|c|c|}
\hline & 町䟿日 & 曜日 & 天侯 & 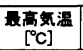 & $\begin{array}{c}\text { 低低温 } \\
{\left[{ }^{\circ} \mathrm{C}\right]}\end{array}$ & $\begin{array}{c}\text { 平均湿度 } \\
{[\%]}\end{array}$ & $\begin{array}{c}\text { 平均風速 } \\
{[\mathrm{m} / \mathrm{s}]}\end{array}$ \\
\hline 春 & $1997 / 4 / 16$ & 水曤日 & $\begin{array}{l}\text { 晴睹々量 } \\
\text { 量一睛雨 }\end{array}$ & 15.7 & 8.9 & 54 & 3.3 \\
\hline $\mathbf{2}$ & $1997 / 7 / 16$ & 水霞日 & 薄量 & 35.0 & 25.5 & 62 & 3.1 \\
\hline 秋 & $1997 / 10 / 16$ & 水矐日 & 睛後一睛量 & 21.0 & 14.0 & 48 & 3.6 \\
\hline 冬 & $1998 / 1 / 21$ & 水曜日 & $\begin{array}{c}\text { 快睛 } \\
\text { 快暗 }\end{array}$ & 13.6 & 0.4 & 46 & 3.0 \\
\hline
\end{tabular}

これらの違いを定量化するために, 首都圏在住の ライフライン防災の専門家（大学教官 2 名 : 地震工 学, 研究所勤務 1 名 : 地震防災, 電力会社 5 名 : 工 務部）を対象としたアンケート調査とブレインス トーミングを実施した。アンケート調査から得よ うとした指標は, 以下の 3 つ, (1)電力消費対象機器 $k$ 間の重み $\left(H_{k i}\right)$, (2)停電時に電力消費対象機器 $k$ の 使用を我慢できる時間 $t_{p}$, (3)電力需要パターン $i$ 間 の重み $\left(r_{i}\right)$, である. なお, (1)は必要度関数の最大 値であり，(2)は慣れ・遅れ関数 $m_{i k}(t)$ および機能支 障関数 $f_{i k}(t)$ を設定するためである.

\section{(2) 調査方法}

調査は, 本研究を共同で進めてきた研究会のメ ンバー 8 名を対象として行われた. アンケートを行 
うに際しては，回答者が主観的な判断を極力加え ないようにすることに重点を置き，アンケート調 査はヒアリング形式で実施した. さらに，ヒアリン グ結果を集計し，その結果を見せながら，回答者全 員が相互に自分がなぜそのような回答に至ったの かの理由を説明し，全員が納得できる值を最終的 に決定した，なお，評価を行う際の基本的な立場と しては，住宅については住民の立場から，オフィ ス, 工場, 店舗/飲食店については, 経営者あるい は管理者の立場からの影響度を評価した。

\section{(3) 質問項目}

まず,「電力消費対象機器間の重み」を決めるに は, 「普段の生活において機器 $k_{1}$ と機器 $k_{2}$ を比較す ると, どちらがどのくらい必要（重要）であるか」
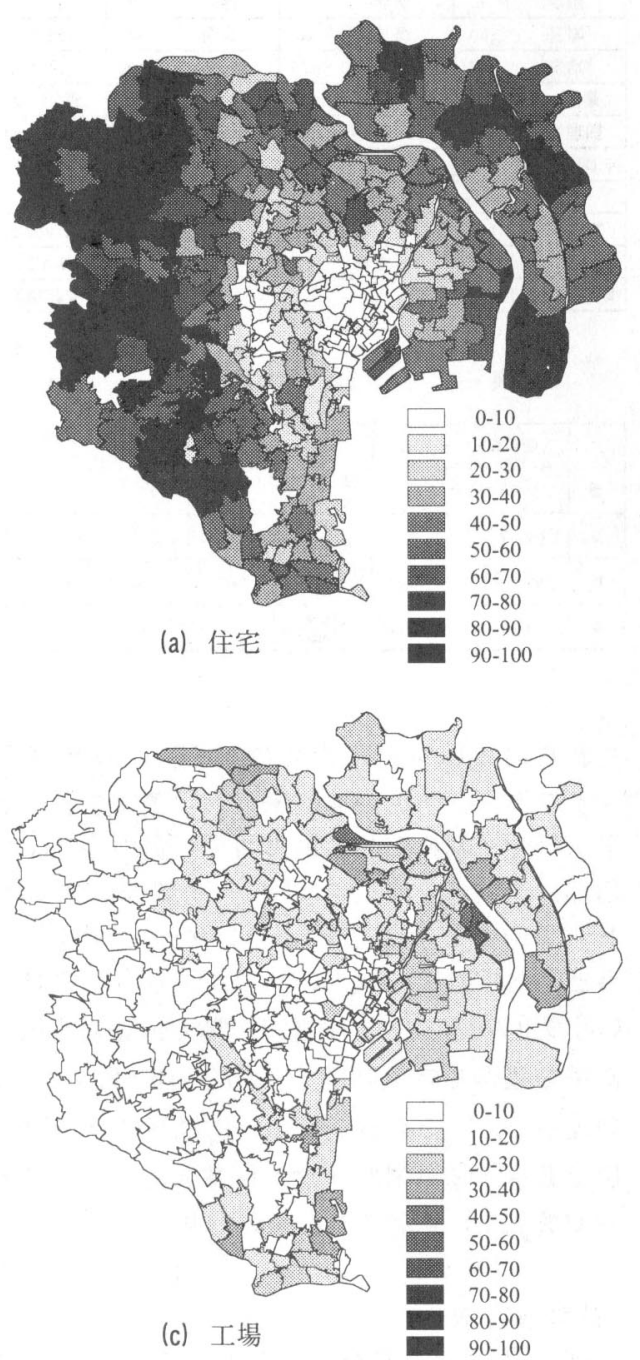

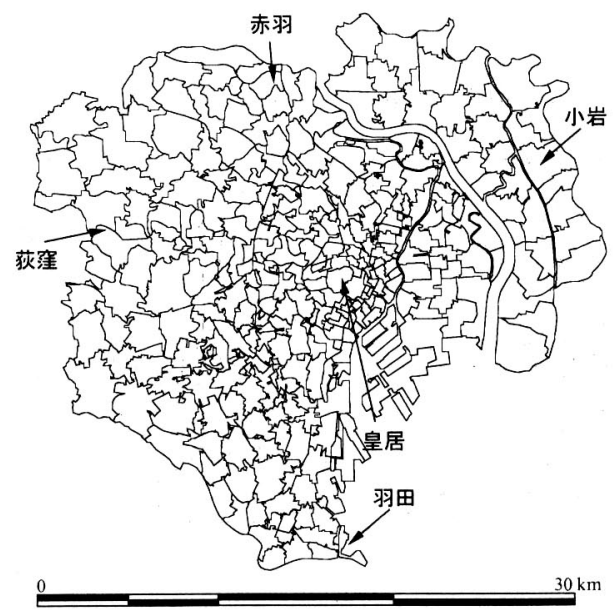

図－8 東京 23 区の配電エリア区分
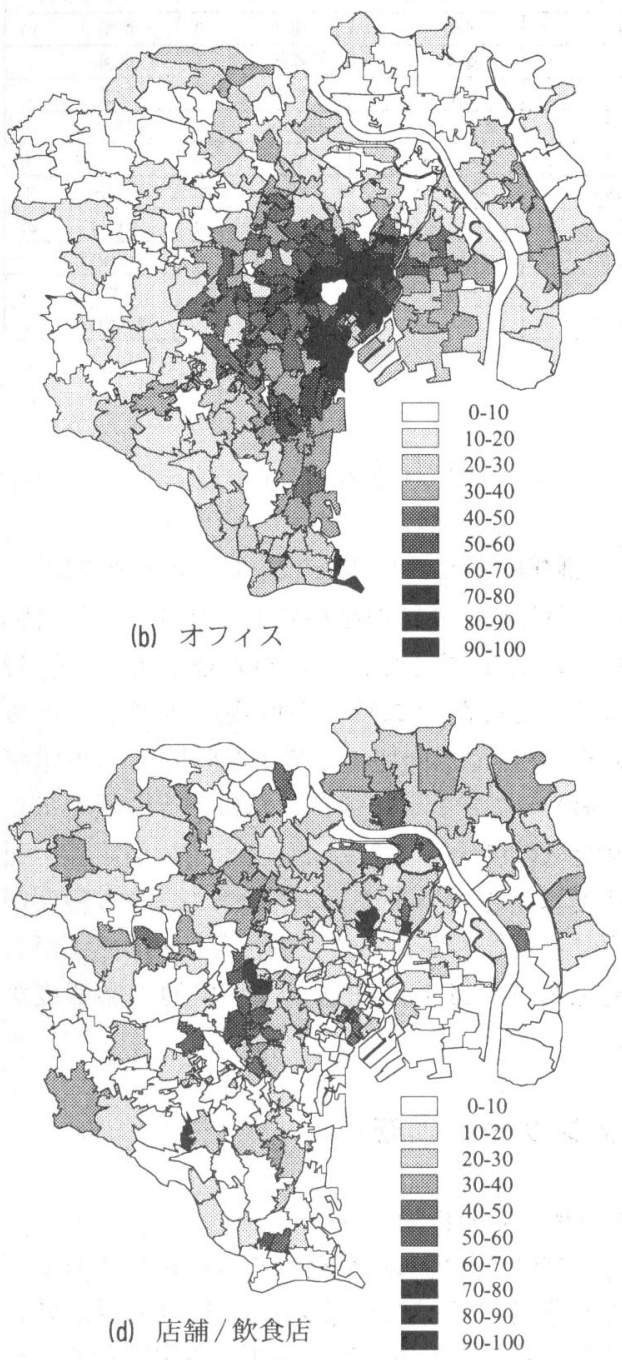

夏） 
といった数值を確定させる必要がある. そこで質 問 1 では, 照明が不可欠である時間帯は「照明」の 重要度を 10 とし，これを基準として各電力消費対 象機器の重みを「照明」に対する比の形で質問し た. 照明を基準としたのは, (1) 4 つの電力需要パ ターンに共通する機器である, (2)必要とされる程 度が大きい, からである. 質問 2 は, 慣れ・遅れ関 数の影響の発現の遅れを表すパラメータ $\left(t_{p}\right)$ を決定 するための「停電時に機器 $k$ の使用を我慢できる時 間」についての質問である. 各電力消費対象機器が 必要となる程度や我慢できる時間は, 時刻によっ て異なることから，各設問では，「その機器をまさ に必要としている場合」を想定して答えてもらっ た.

\section{(4) 評価結果}

以上のようにして行ったヒアリング結果とブレ インストーミングの結果を表ー 1 〜表ー 3 に示す. ヒアリング結果を見ると, 電力消費対象機器ごと の重要度には, かなりの差があることが判明した. これは単純な電力の消費量だけでは, 対象機器の 必要度は決まらないこと, 停電の影響度の評価に 際しても, 対象機器ごとの重要度を考慮する必要 性が示されているものと考えられる．また各電力 消費機器の使用を我慢できる時間についても同様 に, 対象機器ごとに大きく異なる結果となった。

なお電力需要パターン間の重み $r_{i}$ は, 本研究では 1 とした.

\section{4. 東京 23 区の配電エリアヘの適用}

（1）電力需要および地域特性データベースの椎築 本研究で提案する停電影響度評価モデルを, 東 京 23 区の配電エリアに適用するにあたり，必要と なるデータベースの構築を行った. すなわち, 東京 23 区内の配電用変電所エリアマップ（图一8），お よび各配電用変電所の季節別電力需要 (時間稼働) からなる電力需要データベースを G I S 上に構築し た. 本研究では, 各季節の代表と見なせる表一 4 に 示す記録日の電力需要データを選んだ．次に，平成 7 年度国勢調査 ${ }^{21)}$ と平成 8 年度事業所・企業統計調 查 $^{22)}$ の統計デー夕をGISに取り込んで, 地域特性 データベースとした．具体的には国勢調查から「人 口」と「世帯数」を, 事業所・企業統計調査から「事 業所数・営業所」「工場・作業所・鉱業所」「店舗・ 飲食店」を算出した.

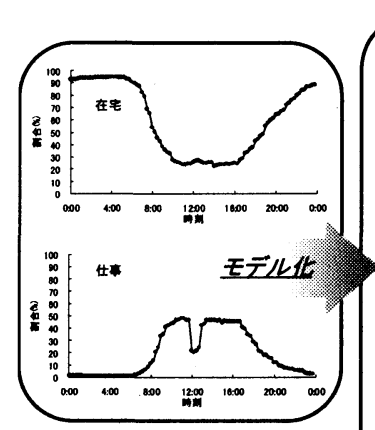

(a) NHK 国民生活時間調査 による在宅, 仕事を している人の割合 ${ }^{17)}$

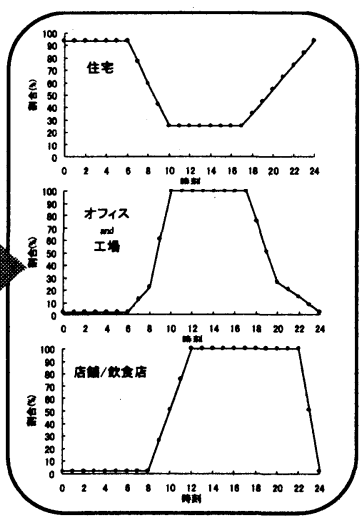

(b) 各パターンごとの在 宅および㗢いている 人の割合

図ー10 在宅人数および従業員数の時間推移のモテル化

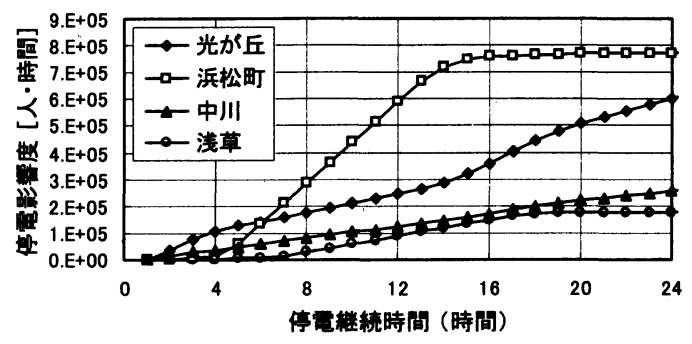

(a) 而：AM6:00 停電発生

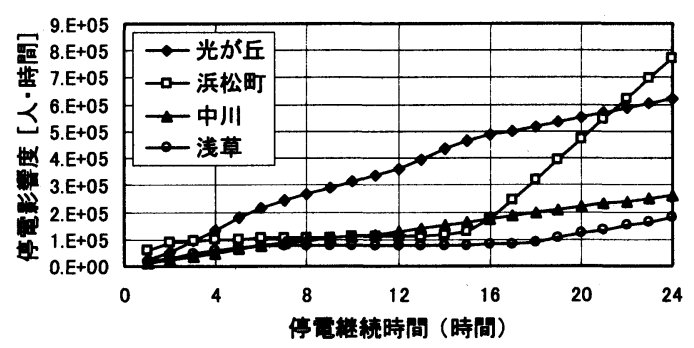

(b) 更: PM6:00 停電発生

図-11 停電影響度の時間変化

\section{（2）電力需要特性分析}

各季節ごとの東京 23 区内の電力需要デー夕を利 用して, 文献 8) の手法を用いて, 電力需要の 4 つ のパターン（住宅，オフィス，工場，店舗/飲食店） の基本カーブの作成, および各配電エリアにおけ る 4 つのパターンの構成率 (寄与率 $C_{j i}$ ) を算出し た. 図ー 9 は，4 パターンの寄与率の分布を示して いる.「住宅タイプは郊外を中心に分布」,「オフィ スタイプは皇居周辺の都心部を中心に分布」,「工 場タイプは臨海部や荒川沿いに分布」,「店舗 / 飲食 店は上野，新宿，渋谷といった繁華街，鉄道沿線沿 


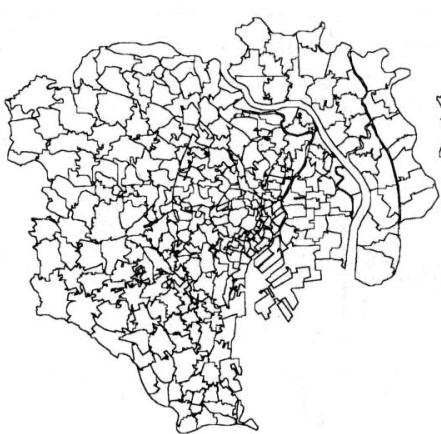

(a) 2 時間後

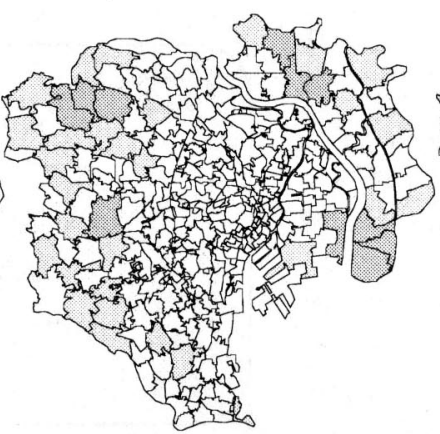

(b) 4 時間後

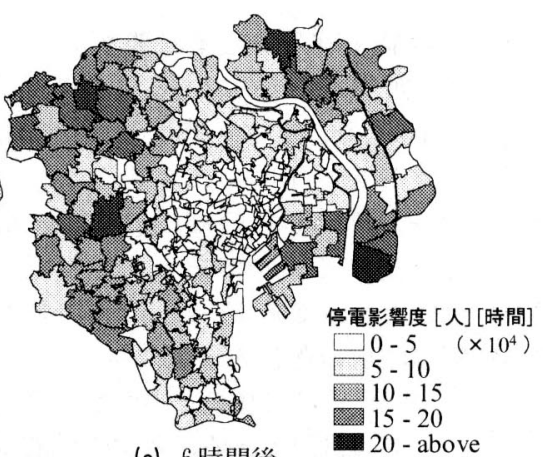

(c) 6 時間後

図ー12 各配電エリアの停電継続時間ごとの停電影響度 : 夏 AM2:00 停電発生

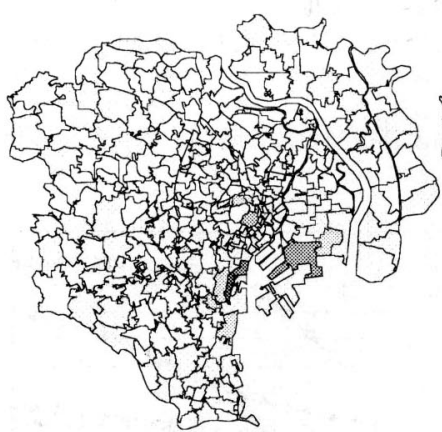

(a) 2 時間後

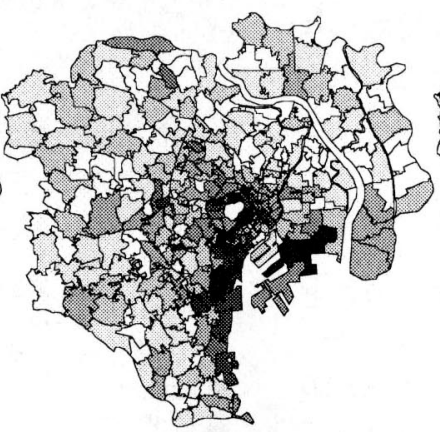

(b) 4 時間後

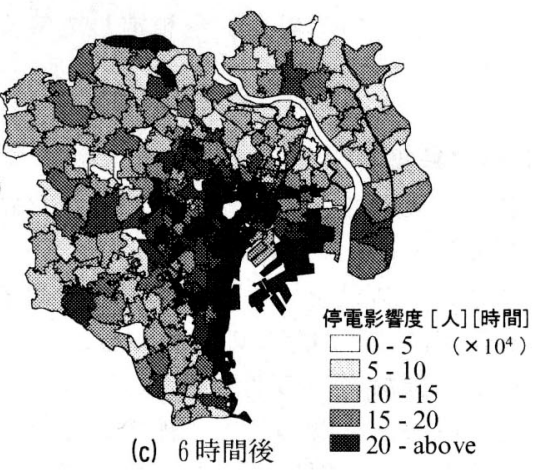

(c) 6 時間後

図-13 各配電エリアの停電継続時間ごとの停電影響度 : 夏 AM8:00 停電発生

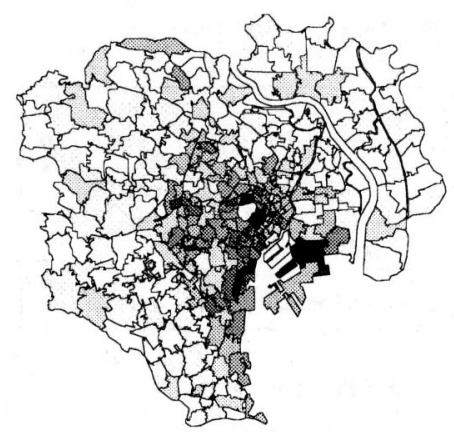

(a) 2 時間後

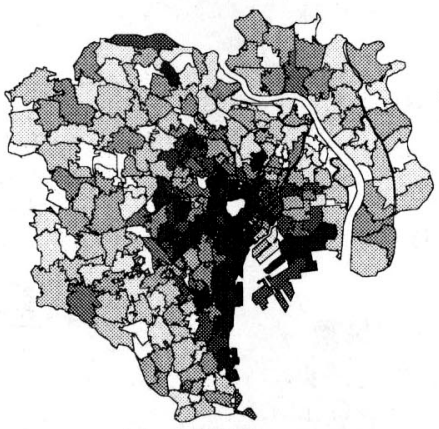

(b) 4 時間後

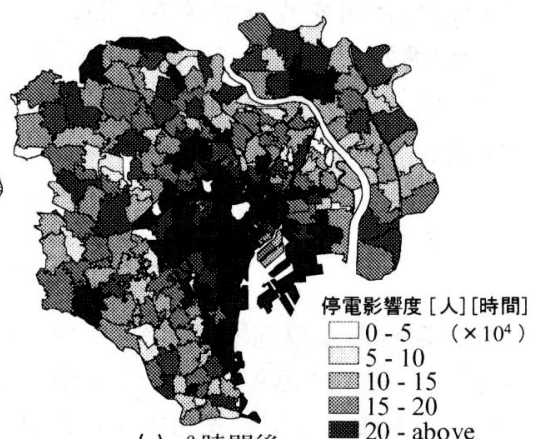

(c) 6 時間後

図－14 各配電エリアの停電継続時間ごとの停電影響度 : 夏 PM2:00 停電発生

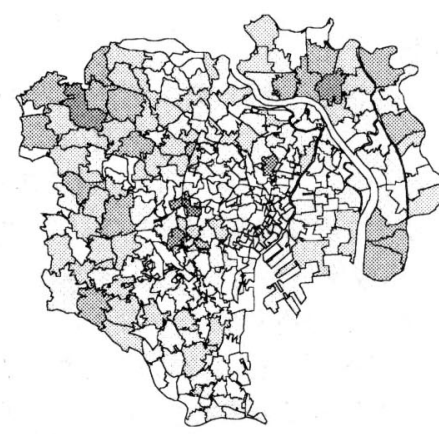

(a) 2 時間後

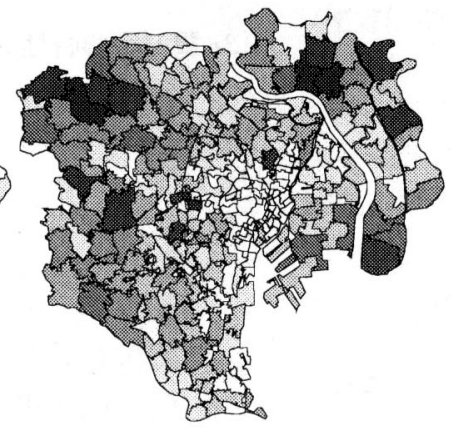

(b) 4 時間後

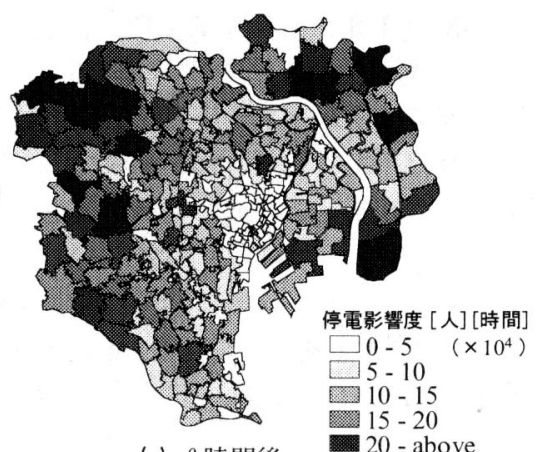

(c) 6 時間後

図ー15 各配電エリアの停電継続時間ごとの停電影響度 : 夏 PM8:00 停電発生 
いに分布」していることが示され，これらは実際の 状況とよく一致している.

\section{(3) 人口の 1 日による変動}

1 日の時刻により, 各パターンに属する人々の人 数は大きく変動する. 本研究では, 住宅, オフィス, 工場, 店舗 / 飲食店の各パターンごとに 1 日の人口 動向を表現する簡単なモデルを作成し， $R_{j i}(t)$ とし た. 在宅者および就業者について, NHK 国民生活時 間調査の「在宅」,「仕事」をしている人の割合か ら, 図ー10に示すようにモデル化を行った．住宅 については, 在宅している人口の $100 \%$ を国勢調査 から求めた各配電エリアの人口とした。オフィス および工場については, 日中の最大値において全 従業員が就業しているものと仮定した. 店舗 / 飲食 店タイプについては, 繁華街に位置して夜間に電 力を使用して営業するタイプを想定していること から, 夜間まで操業していると仮定した。また店 舗/飲食店では, その店に居合わせたお客も影響を 受けることから, 従業員と客の人数を $R_{4 j}(t)$ とし た. 客の数は東京都の平成 4 年度商業統計調查報告 （一般飲食店）から, 店舗 1 軒あたりの売上および 客一人あたりの消費額がわかるので, これらの值 から店舗 / 飲食店 1 軒あたりに平均して 7.99 人が 滞在していると仮定した。

\section{(4) 停電影響度の算出}

式 (3) に従って停電の影響度を算出した. 図ー 11 (a) および (b) は，それぞれ夏の暑い日の午前 6 時, および午後 6 時に停電が発生した場合の, 停電の影 響がどのように上がっていくのかを，適当な 4 つ の配電エリアを対象として示したものである.

午前 6 時に停電が発生した場合, 住宅の多い光が 丘はすぐに影響が発生し出すのに対し, オフィス や工場, 店舗 / 飲食店の多い, 他の 3 つの配電エリ アは停電発生後 4 時間程度までは影響が小さい. 停 電発生から 4 時間後からオフィスの多い浜松町の 影響が急激に增加しているが, 営業時間が終わる 夕刻を境に増加の割合は減少する. 店舗/飲食店の 多い浅草は, 停電の影響が出始める時刻および影 響の増加が小さくなる時刻は, オフィスに比べる と 2 時間ほど遅いのがわかる. 午後 6 時に停電が発 生した場合は, 住宅の多い光が丘の影響度の増加 と比べると, 他の 3 つの配電エリアの影響度の増加 は緩やかである.しかしオフィスや工場が営業を 開始する停電から 16 時間後には浜松町の影響は急 激に增加している.

図ー12〜図-15は，それぞれ夏の暑い日の午前

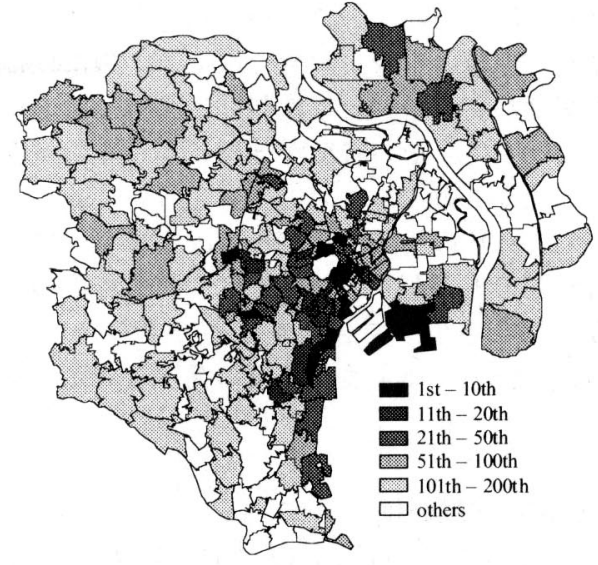

(a) PI।の大きさによる順位

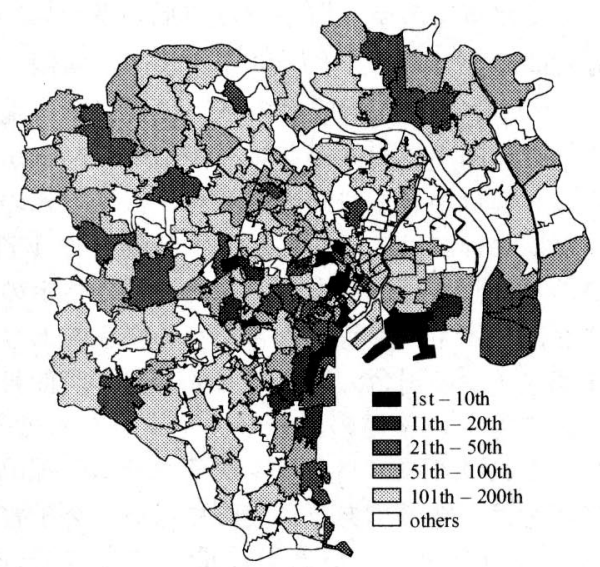

(b) $\mathrm{PI}_{2}$ の大きさによる順位

図-16 潜在的停電危険度の順位の分布

2 時, 午前 8 時, 午後 2 時および午後 4 時に停電が 発生した場合の，停電発生から 2 時間，4 時間， 6 時間後の停電の影響度の違いを示したものである. 深夜に停電が発生した場合は, 多くの人は活動を 停止しているので停電の影響はすぐには表れない. その後, 郊外の住宅地から徐々に停電の影響が出 始めるが, 都心部の住宅地以外の地域はほとんど 影響が表れていない，深夜の停電影響度は，他の停 電発生時刻と比べると小さいことがわかる．早朝 に停電が発生した場合は, 初めは郊外の住宅地で 影響が出始めるが，オフィスや工場の営業活動が 始まると同時に, 停電の影響度は都心部, 臨海部で 大きくなってくる，日中に停電が発生した場合は， 都心部（丸の内，新宿など）や臨海部における影響 が顕著となる．また日中の活動時間帯における停 電のために，影響度の絶対値も大きくなる，夜間に 停電が発生した場合は，都心部ではオフィスや工 
場は営業活動が終了しており, 周辺部の郊外を中心 に徐々に停電の影響が大きくなる．このように停電 の影響度が発生時刻と継続時間によって大きく変化 するとともに，その特徵が地域によっても大きく異 なることがわかる、

なおこれらの結果は, 個々の配電エリアに，ある 継続時間の停電が発生した際に, どの程度の影響が 及ぶのかを定量的に評価するものであり, 東京 23 区全体が停電するような停電の発生を想定している わけではない.

\section{(5) 停電危険度評価}

図ー 16 は, 式 (12)，(13)に従って算出した, $t_{d}=2$ 時間における停電危険度指標 $\left(P I_{1}, P I_{2}\right)$ の大きさによ る順位の分布である. $P I_{1}, P I_{2}$ は危険度を算出する 積分時間の違いから，PI1 はオフィス・店舗/飲食 店の, $P I_{2}$ は住宅の構成率の高いエリアの停電影響 度を高く評価する傾向があり, 両指標の順位が大き く異なる場合が見られた。これらは住宅以外の需要 カーブにおいては, 需要のピーク時刻とエリア内の 人口のピークが重なるため, 1 日の中で特定の時間 帯における停電の影響が大きくなるからであり, 逆 に住宅タイプの場合, 深夜も含めてどの時間帯にも コンスタントに停電の影響が発生するためである. しかしこれは 4 つのパターンがそれぞれ支配的な工 リアにおける特徵であり, 実際には個々の配電エリ アは 4つのパターンが適当に重なり合っているた め, 全体的には概ね同傾向の危険度を示す結果と なった.これらの指標により高い危険度が算定され た配電エリアについて, 東京電力の関係者と議論し た結果, 「東京電力の専門家や担当者たちが, 業務 を通して停電による影響が大きいだろうと認識して いるエリアと, その多くが一致している」との結論 に至った。これは提案する停電危険度指標が, 経験 豊かな現場の担当者や専門家の意見に近い評価を行 える事を意味しており, 本指標の有用性を示してい ると考えられる。

\section{5.おわりに}

本研究では, 日常的に発生する停電を対象とし て, 停電の発生時刻および継続時間に応じた, 停電 影響度を定量的に評価する手法の提案を行った。す なわち,「停電の影響」を「平常時に行っている生 活活動ができなくなってしまう状態」と定義し， 「平常時ならば行っているはずの生活活動の重要さ の合計」を「停電の影響度」として評価する手法を
構築した．また提案手法を東京 23 区の配電用変電 所に適用し, 電力需要分析ならびに各配電エリア の停電影響度マップの作成を行った．停電はいつ 発生し, どの程度継続するのかを事前に知ること は困難であることから, 発生時刻と継続時間を任 意選択してその影響度を評価できる点は，本提案 手法の優れた点と言える.

本研究の利用方法としては, 事前の防災対策や 投資の優先順位の決定, 停電復旧時の復旧順位の 決定, 災害時の停電被害の想定, 新しい配電用変 電所設置時やその他の新規設備設置時の決定, な ど電力事業者や都市管理者の戦略的判断を支援す ることが考えられる.また，本研究では東京 23 区 を対象としているため, 他の地域に提案手法を適 用するに当たっては, 対象地域の人々の生活に応 じた電力消費機器の選定と, そこで生活している 人々を被験者としたアンケート調査の実施が必要 であろう。

今後の課題としては, 本研究では停電の影響度 として考慮しなかった, (1)停電による他システム への影響, (2)特別高圧需要家の影響, (3)バック アップ電源装置 / 施設の効果, (4)長期間の停電に よって引き起こされる, 深刻な生活支障ならびに 社会的影響, などが挙げられる.

\section{参考文献}

1) 日本エネルギー経済研究所 計量分析部編: エネルギー・ 経済統計要覧，(財）省エネルギーセンター, 2001.

2) 加藤多郎, 能島暢呂, 亀田弘行 : 都市ライフラインの 地震被害とライフラインシステム間の相互連関の分析, 京都大学防災研究所都市耐震センター研究報告別冊第 3 号, 京都大学防災研究所, 1990 .

3）研究代表者 (片山恒雄): 都市震災の連関および波及効 果の解明之震災想定調查への利用に関する研究, 科学 研究費補助金 (一般研究 B) 研究成果報告書, 1989 .

4) 東京電力株式会社 広報部: 数表で見る東京電力 平成 12 年度版, 2000 .

5）塩野計司, 朱牟田善治 : ユーティリティの震害による 住民の生活支障, 自然災害科学, Vol. 13, No. 2, pp. 193203, 1994.

6）能島暢呂, 亀田弘行, 吉川徹志 : ライフライン地震被 害による居住生活支障の評価に関する研究, 第 21 回地 震工学研究発表会, pp. 329-332, 1991.

7) 能島暢呂, 亀田弘行, 林春男 : 地震時のライフライン 機能障害に対する利用者の対応システムを考虑した生 活支障の評価法, 地域安全学会論文報告集, N o. 3, pp. 195-202, 1993.

8）川崎順子, 長橋純男 : 地震時の上水道機能停止による 生活支障の定量評価に関する研究, 日本建築学会構造 系論文集, No. 503, pp. 45-52, 1998. 
9) 目黒公郎, 副島紀代, 山崎文雄, 片山恒雄 : 電力需要特 性から見た都市の地域分類, 土木学会論文集, N0. 507/ I-30, pp. 255-263, 1995.

10）朝日新聞 : 朝日新聞記事データベース, 1991-2000.

11）土木学会 : 1983 年日本海中部地震震害調査報告書, 1986.

12）研究代表者（鏡味洋史）：1993 年釧路沖地震による被 害の調查研究, 文部省科学研究費突発災害調査研究費成 果総合研究 (A), 1998.

13）研究代表者 (笠原稔): 平成 6 年 (1994) 北海道東方沖地 震およびその被害に関する調査研究, 文部省科学研究費 総合研究 (A) 突発災害調査研究成果報告書, 1994 .

14）（社）土木学会 鳥取県西部地震被害調査団 : 2000 年 10 月 6 日鳥取県西部地震の報告書, 2000 .

15）（社）土木学会 芸予地震被害調査団：2001 年 3 月 24 日芸予地震の報告書, 2001 .

16）片山恒雄, 増井由春 : 1978 年宮城県沖地震による都市
供給施設の被害と復旧-電力施設-, 生産研究, 第 31 巻 6 号, pp. 532-536, 1991.

17）目黒公郎, 永田茂, 立川貴重, 片山恒雄 : 台風 19 号に よる大規模停電の都市機能への被害波及に関する調查研 究一広島地域における大規模停電の影響一, 生産研究, 44 巻 4 号, pp. 194-201, 1992.

18）関西電力株式会社 : 阪神・淡路大震災復旧記録, 1995.

19）愛知県: 平成 12 年 9 月 11 日からの大雨による災害の記 録, 2001.

20） NHK放送文化研究所編：国民生活時間調査1990 (県別), 日本放送出版協会, 1991.

21）（財）統計情報研究開発センター：平成 7 年度国勢調 查小地域集計

22）（財）統計情報研究開発センター：平成 8 年事業所・ 企業統計調査 町丁・大字別集計

(2001. 11. 30 受付)

\title{
EVALUATION OF EFFECTS OF POWER OUTAGE IN URBAN AREAS CONSIDERING THE OCCURRENCE TIME AND DURATION
}

\author{
Yasunori HADA, Jun KAWAKITA, Kimiro MEGURO, Fumio YAMAZAKI \\ and Tsuneo KATAYAMA
}

\begin{abstract}
With urbanization, the amount of electric-power consumption and its ratio to the total energy consumption have increased. Due to this increase, a possible power outage will have a severe impact to the affected urban area. In this study, we propose a quantitative evaluation method of the power outage effects. Power outage is defined as "a situation, in which people cannot do their usual activities" and a power outage effect index is evaluated as a total value of disturbance of various human activities. Proposed method is applied to Tokyo Metropolis and power load characteristics are analyzed. Prepared are maps of the power outage effects for each substation area.
\end{abstract}

